\title{
Synthesis of magnesian calcite at low temperatures and pressures
}

\author{
Yasushi Kitano and Nobuko Kanamori \\ Water Research Laboratory, Faculty of Science, \\ Naguya University, Chikusa, Nagoya, Japan
}

(Received May 25, 1966)

\begin{abstract}
As one of the steps that lead to an understanding of the secretion of magnesian calcite in skeletal parts of marine organisms, the laboratory synthesis of the mineral from aqueous solutions was carried out at low temperatures and pressures. The conditions of the laboratory synthesis of magnesian calcites are shown in this paper. Magnesian calcites are precipitated from calcium bicarbonate solutions containing magnesium ions and certain organic materials such as organic acids, which are found in the body fluids of carbonate-secreting organisms, in various concentrations.
\end{abstract}

Most sedimentary carbonates are derived from the skeletal parts of calcareous marine organisms. These skeletons are composed of the minerals, calcite (magnesium-poor calcite), aragonite (always low in magnesium carbonate), and mag. nesian calcite (magnesium-rich calcite) (Chave, 1954; Lowenstam, 1954; Kitano, 1964). Magnesium carbonate in skeletal calcites is present as a solid solution between calcite and dolomite or magnesite (Chave, 1952; Kitano et al. 1959). And magnesian calcites and aragonite are unstable, relative to calcite, at low temperatures and pressures (Chave et al., 1962; JAnSEN and Kitano, 1963).

Considerable number of studies have been carried out in order to determine the physico-chemical factors controlling the formation of calcite* and aragonite from aqueous solutions (LipPMANN, 1960; Kitano, 1962 a, b; Kitano and Hood, 1962; SimKISs, 1964), and the formation of calcites** and aragonite in skeletal materials (Lowenstam, 1954; Chave, 1654, 1962; Watabe and Wilbur, 1960; Wilbur, 1960; WILBUR and WATABE, 1963); however very little has been done on the mechanisms of the formation of magnesian calcites.

The distribution of magnesian calcites in the skeletal materials of calcareous marine organisms was described (Chave, 1954; Pilkey and Hower, 1960; Pilkey and Goodeli, 1963; Lowenstam, 1961, 1963). Laboratory synthesis of this spectrum of minerals was accomplished only at high temperatures and pressures (HARKER and Tuttle, 1955; Graf and Goldsmith, 1955; Goldsmirh, 1959; Goldsmith and HEARD, 1961).

* Magnesium-poor calcite.

** Magnesium-poor and -rich calcites. 
One of the steps that lead to an understanding of the secretion of magnesiumrich calcite in skeletal parts of marine organisms is the laboratory synthesis of the mineral from aqueous solutions at low temperatures and pressures. This paper describes the conditions of the laboratory synthesis of magnesian calcites. Magnesian calcites are precipitated from calcium bicarbonate solutions containing mag. nesium ions and certain organic materials such as organic acids, which are found in the body fluids of carbonate-secreting organisms, in various concentrations.

\section{EXPERIMENTAL}

A calcium bicarbonate solution $\left(0.35-0.37 \mathrm{~g} / 1 \mathrm{Ca}^{+2}\right)$ was prepared by bubbling carbon dioxide gas for one day in calcium carbonate suspended distilled water. This was allowed to stand for thirty minutes, filtered, and bubbled with carbon dioxide gas for additional $2 \mathrm{hr}$.

A magnesium chloride solution $\left(24 \mathrm{~g} / \mathrm{l} \mathrm{Mg}^{+2}\right.$ ) was prepared from reagent grade $\mathrm{MgCl}_{2} \cdot 6 \mathrm{H}_{2} \mathrm{O}$ and distilled water.

Solutions of sodium or acid salts of citric, malic, pyruvic, succinic and chondroitin sulfuric acids, at a $\mathrm{pH}$ of 7.0 and with a concentration of $13.5 \mathrm{~g} / 1$, were pre. pared in distilled water.

The three solutions were mixed in various proportions, as shown in Tab. 1 and 2, put in Erlenmeyer flasks, plugged with cotton, and allowed to stand at a constant temperature for 2 to 8 weeks. Over this period of time the carbon dioxide gas gradually escaped and carbonate crystals precipitated. The $\mathrm{pH}$ of the solutions was measured at the beginning and the end of each experiment. At the end of each experiment the calcium concentration in the filtered solution was determined by adding hydrochloric acid and then boiling to remove carbon dioxide, and titration at a $\mathrm{pH}$ of $9.5-10.0$ with EGTA standard solution using Zincon* as an indicator.

The mineralogy of the precipitated carbonate was determined by X-ray diffraction. Calcium in the carbonate was determined by EGTA titration and magnesium was determined by the color intensity measurement of the complex between magnesium ions and Thymolphthalein Complexone at a pH 9.5-10 (Kanamori and KITANO, in press).

\section{Results AND Discussion}

A mother solution must contain magnesium ions for the precipitation of mag. nesian calcite, which is of calcitic lattice configuration.

Previous experiments, Kirano et al. (1962), showed that, in the absence of organic compounds, magnesium ions favor the precipitation of aragonite, which contains little magnesium in the lattice, from supersaturated calcium bicarbonate

* Zincon (2-carboxy-2'-hydroxy-5-sulphoformazyl benzene). Solution was prepared by dissolving $0.2 \mathrm{~g}$ in $5 \mathrm{ml}$ of $0.1 \mathrm{~N}$ sodium hydroxide solution and diluted with distilled water to $100 \mathrm{ml}$. 
solutions. Preliminary results, reported by Kitano and HooD (1965), suggested that organic materials influenced this precipitation, and in some cases favored the formation of calcite, even in the presence of magnesium ions. This could accomplish the precipitation of magnesian calcite at low temperatures and pressures. The experimental results are shown in Tables 1 and 2, and in Fig. 2, 3, 4 and 5 based on the tables.

The values for the differences in spacing of (0114) reflection between the pure calcite and precipitated calcites were plotted against magnesium carbonate content as chemically determined in Fiy. 1 on the basis of Table 1. The linear relationship between these variables indicates that magnesium carbonate is contained as a form of magnesian calcite.

The present experiments indicate (see Table 1) that sodium citrate and sodium malate favor the formation of magnesian calcite, probably by complexing calcium ions, reducing the precipitation rate of carbonate, giving a stable calcitic lattice configuration and causing a capture of magnesium in the calcitic lattice.

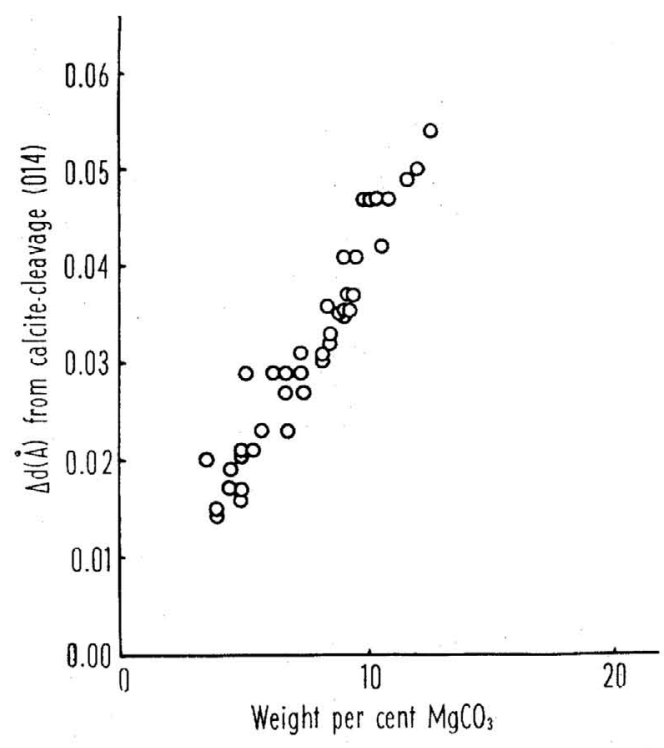

Fig. 1. The relation between magnesium carbonate content and interplanar spacing.

Further, an increase in concentation of both magnesium ions and these organic materials causes formation of a magnesium-richer calcite (see Fig. 2 and 3).

Table 2 shows that an increase in temperature causes an increase in the magnesium content of the calcite when sodium citrate, sodium pyruvate and sodium malate are added (see Fig. 4 and 5 ). Chondroitin sulfate and sodium succinate, at all studied temperatures and concentrations, allow primary aragonite precipitation 


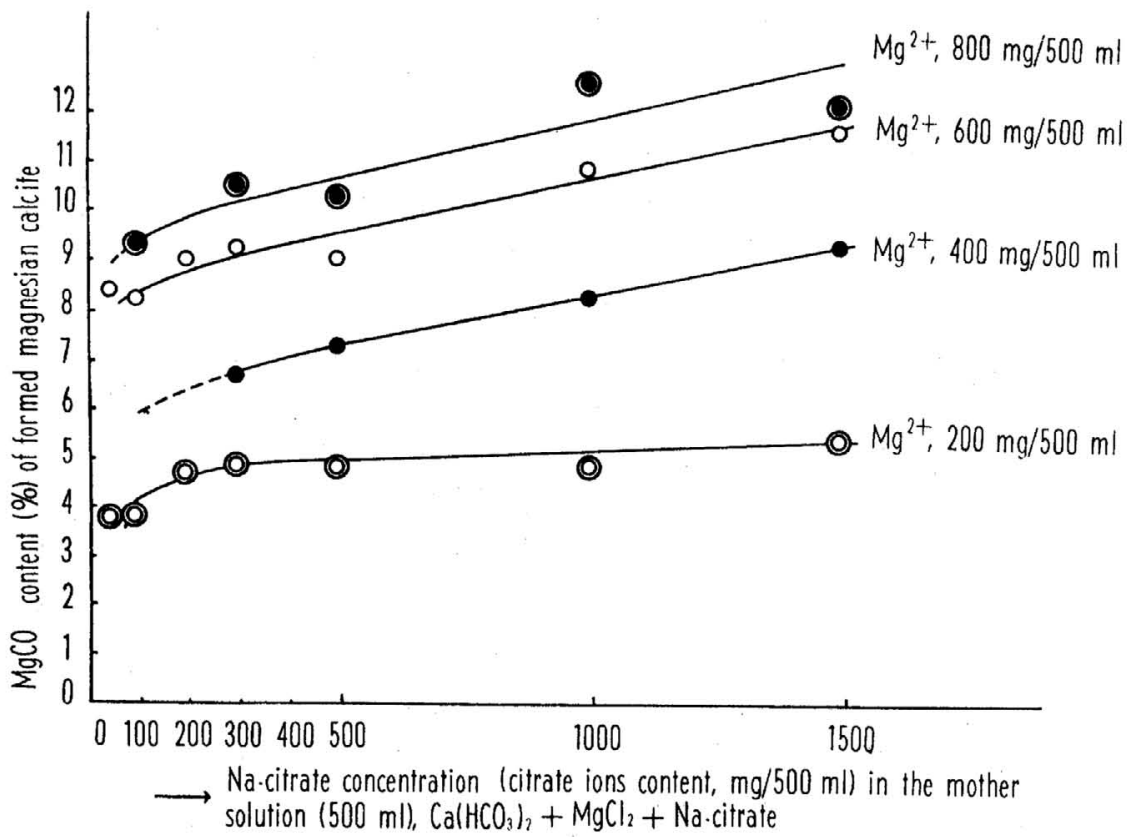

Fig. 2. $\mathrm{MgCO}_{3}$ content of magnesian calcite formed from the $\mathrm{Ca}\left(\mathrm{HCO}_{3}\right)_{2}$ solution containing $\mathrm{MgCl}_{2}$ and sodium citrate. $20 \pm 1^{\circ} \mathrm{C}$.

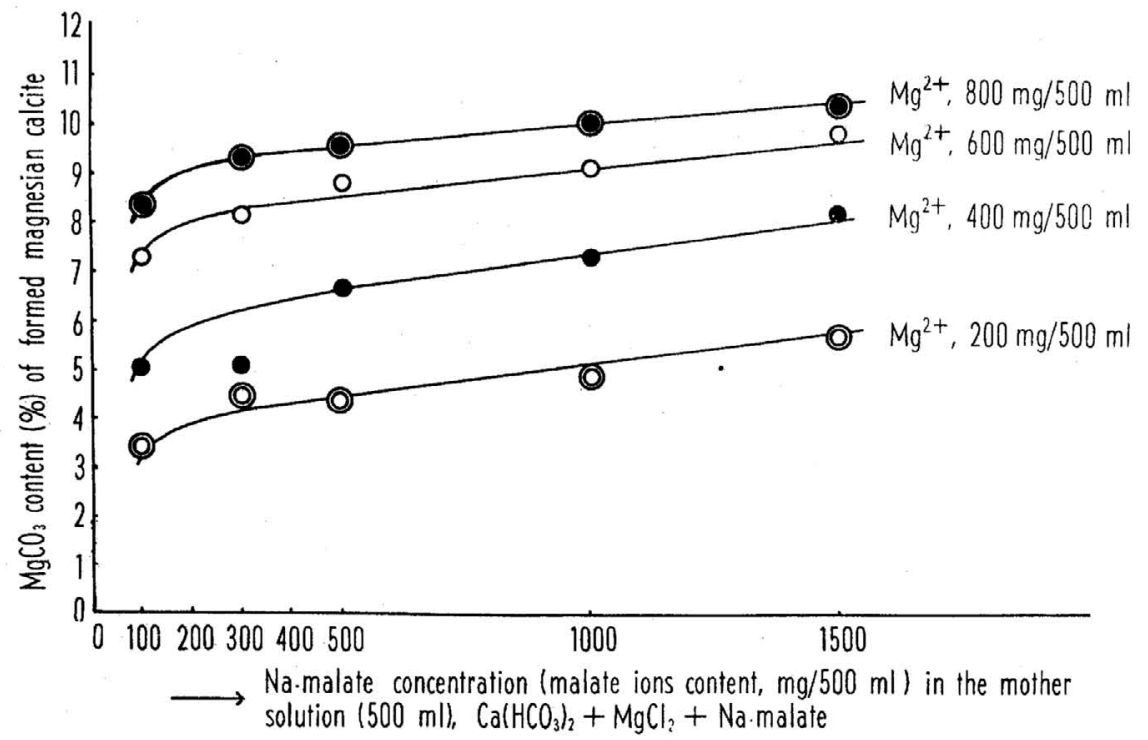

Fig. 3. $\mathrm{MgCO}_{3}$ content of magnesian calcite formed from the $\mathrm{Ca}\left(\mathrm{HCO}_{3}\right.$ ); solution containing $\mathrm{MgCl}_{2}$ and sodium malate. $20 \pm 1^{\circ} \mathrm{C}$. 


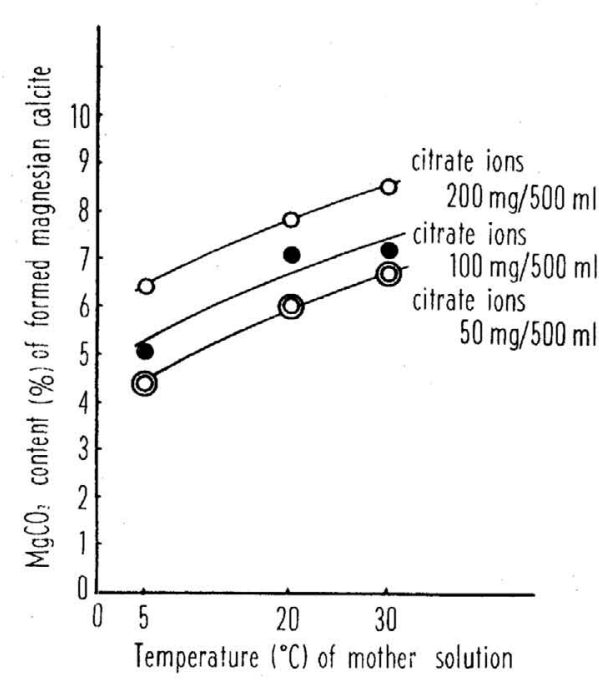

Fig. 4. $\mathrm{MgCO}_{3}$ content of magnesian calcite formed from the calcium bicarbonate mother solution ( $500 \mathrm{ml}$ ) containing $\mathrm{MgCl}_{2}\left(\mathrm{Mg}^{2+}, 400 \mathrm{mg} / 500 \mathrm{ml}\right)$ and sodium citrate (citrate ions, $50-200 \mathrm{mg} / 500 \mathrm{ml}$ ).

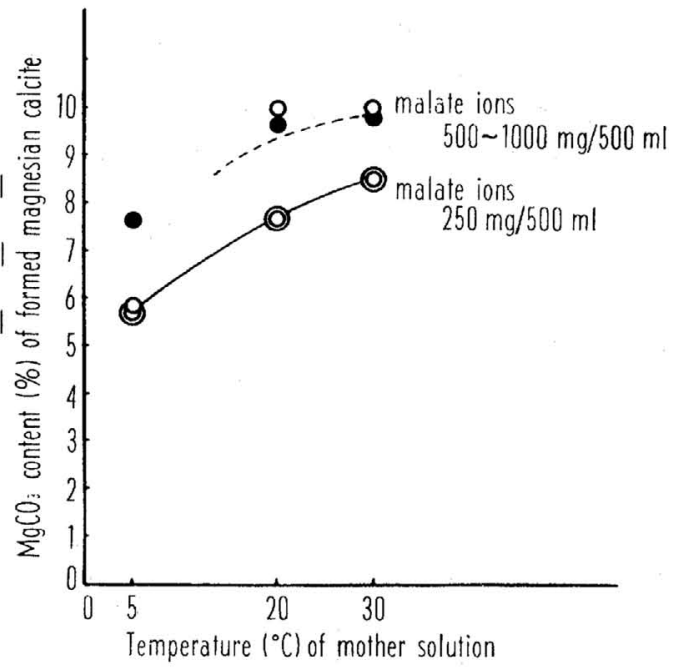

Fig. 5. $\mathrm{MgCO}_{3}$ content of $\cdot$ magnesian calcite formed from the calcium bicarbonate mother solution ( $500 \mathrm{ml}$ ) containing $\mathrm{MgCl}_{2}\left(\mathrm{Mg}^{2+}, 400 \mathrm{mg} / 500 \mathrm{ml}\right)$ and sodium malate (malate ions, $250-1000 \mathrm{mg} / 500 \mathrm{ml}$ ).

in the presence of magnesium ions, probably by having a little influence on the precipitation rate and the precipitation of polymorphic crystals of calcium carbonate (Kitano et al., 1965).

While the magnesium carbonate content of magnesian calcites increases with increasing temperature and concentrations of magnesium ions and the organic compound in a mother solution, it differs with the kind of organic compound.

The immediate interpretations and the real mechanisms, which fit the present results. have not been determined as yet. However, it can be said that the organic molecules, favoring the formation of magnesian calcite. complex calcium ions, gradually release the ions* and reduce the precipitation rate of carbonate. At this point, it is noted that the amounts of organic molecules such as citrate, malate and pyruvate are very small as compared with the amounts of calcium and magnesium ions as seen from Tables 1 and 2.

It was reported that the magnesium carbonate concentration in skeletal magnesian calcites of marine organisms increases with increasing temperature and salinity of sea water, and varies with the phylogenetic level of the organism (Chave, 1954; Pilkey et al., 1960, 1963; Lowenstam, 1961, 1963).

If we can consider that the increase in salinity means an increase in the concentration of magnesium ions, and that a biological group or species can be charac-

* No microorganisms occurred in the solutions. 
terized by a metabolic cycle involving organic compounds, in other words, by the composition and concentration of organic materials in a body fluid, the present laboratory results seem to have some analogy to the observational facts of natural calcareous marine organisms concerning the conditions of magnesian calcite formation.

Table 1. Formation of magnesian calcite in

\begin{tabular}{|c|c|c|c|c|c|c|c|c|}
\hline \multicolumn{9}{|c|}{ Composition of mother solution } \\
\hline \multicolumn{9}{|c|}{ at the start } \\
\hline \multicolumn{2}{|c|}{$\mathrm{Ca}\left(\mathrm{HCO}_{3}\right)_{2}$} & \multicolumn{2}{|c|}{$\mathrm{MgCl}_{2}$} & \multicolumn{3}{|c|}{ Organic material } & \multirow{2}{*}{$\begin{array}{c}\text { distilled } \\
\text { water } \\
\text { ml }\end{array}$} & \multirow[b]{2}{*}{$\mathrm{pH}$} \\
\hline $\mathrm{ml}$ & $\begin{array}{c}\mathrm{Ca}^{2+} \\
\mathrm{mg} \\
\end{array}$ & $\mathrm{ml}$ & $\begin{array}{c}\mathrm{Mg}^{2+} \\
\mathrm{mg} \\
\end{array}$ & material & $\mathrm{ml}$ & $\begin{array}{c}\text { radicle } \\
\mathrm{mg}\end{array}$ & & \\
\hline 500 & 189 & 3.3 & 200 & Na-Citrate & 0.4 & 50 & 22 & 6.19 \\
\hline$" \prime$ & $\prime \prime$ & $" 1$ & $" 1$ & u & 0.8 & 100 & 21 & 6.18 \\
\hline$\prime \prime$ & $" 1$ & $"$ & $" 1$ & "I & 1.6 & 200 & 20 & 6.19 \\
\hline$\prime \prime$ & $" 1$ & $" \prime$ & $" \prime$ & $" \prime$ & 2.4 & 300 & 19 & 6.18 \\
\hline$" \prime$ & $" \prime$ & $" \prime$ & $" 1$ & "I & 4 & 500 & 18 & 6.18 \\
\hline$" \prime$ & $" \prime$ & " & $" 1$ & $" \prime$ & 8 & 1000 & 14 & 6.17 \\
\hline$" \prime$ & $" t$ & $" \prime$ & $" 1$ & $\begin{array}{l}\prime \prime \prime \\
\prime \prime\end{array}$ & 12 & 1500 & 10 & 6.17 \\
\hline$" \prime$ & $" \prime$ & 6.6 & 400 & $" \prime$ & 2.4 & 300 & 16 & 6.20 \\
\hline$" 1$ & $" \prime$ & $" 1$ & $" \prime$ & "l & 4 & 500 & 14 & 6.19 \\
\hline$" \prime$ & $" \prime$ & $" \prime$ & $" \prime$ & "l & 8 & 1000 & 10 & 6.19 \\
\hline$" \prime$ & $" \prime$ & $"$ & $" \prime$ & $" \prime$ & 12 & 1500 & 6 & 6.18 \\
\hline " & $\prime \prime$ & 10 & 600 & $\prime \prime$ & 0.4 & 50 & 15 & 6.19 \\
\hline "I & 11 & $" \prime$ & $" \prime$ & $" 1$ & 0.8 & 100 & 14 & 6.17 \\
\hline$\prime \prime$ & $" \prime$ & $" \prime$ & $" 1$ & $\prime \prime$ & 1.6 & 200 & 13 & 6.15 \\
\hline "I & $" \prime$ & $" \prime$ & $"$ & $" \prime$ & 2.4 & 300 & 12 & 6.15 \\
\hline$\prime \prime$ & $\prime \prime$ & $" \prime$ & $" 1$ & " & 4 & 500 & 11 & 6.10 \\
\hline$\prime \prime$ & $" \prime$ & $\prime \prime$ & $" \prime$ & $" 1$ & 8 & 1000 & 7 & 6.10 \\
\hline$" \prime$ & $" 1$ & $" \prime$ & $" 1$ & $" \prime$ & 12 & 1500 & 3 & 6.10 \\
\hline$\prime \prime$ & $" \prime$ & 13.2 & 800 & $" \prime$ & 0.8 & 100 & 11 & 6.02 \\
\hline$" \prime$ & $" \prime$ & 11 & 11 & $" \prime$ & 2.4 & 300 & 9 & 6.02 \\
\hline$" \prime$ & $" \prime$ & "I & $" \prime$ & $" \prime$ & 4 & 500 & 8 & 6.02 \\
\hline$" \prime$ & $" \prime$ & $" \prime$ & $" \prime$ & " & 8 & 1000 & 4 & 6.02 \\
\hline$n$ & $\prime \prime$ & $\prime \prime$ & $" \prime$ & $" \prime$ & 12 & 1500 & 0 & 6.02 \\
\hline 500 & 189 & 3.3 & 200 & Na-malate & 0.8 & 100 & 21 & 6.10 \\
\hline$" I$ & "I & $" 1$ & $n$ & "I & 2.4 & 300 & 19 & 6.17 \\
\hline$\|$ & "I & $\prime \prime$ & $" \prime$ & $" \prime$ & 4 & 500 & 18 & 6.10 \\
\hline$" \prime$ & $" \prime$ & $\prime \prime$ & $" 1$ & $" \prime$ & 8 & 1000 & 14 & 6.10 \\
\hline$\prime \prime$ & $" \prime$ & "I & $" \prime$ & "I & 12 & 1500 & 10 & 6.12 \\
\hline$\prime \prime$ & $" \prime$ & 6.6 & 400 & $" \prime$ & 0.8 & 100 & 18 & 6.00 \\
\hline$" \prime$ & $\|$ & $"$ & $"$ & $" \prime$ & 2.4 & 300 & 15 & 6.02 \\
\hline "l & $" \prime$ & $" \prime$ & $" \prime$ & $" \prime$ & 4 & 500 & 14 & 6.00 \\
\hline$\|$ & $\prime \prime$ & "I & $\prime \prime$ & $" \prime$ & 8 & 1000 & 10 & 6.00 \\
\hline$" \prime$ & $"$ & $" \prime$ & $"$ & $"$ & 12 & 1500 & 6 & 6.00 \\
\hline$\prime \prime$ & $" \prime$ & 10 & 600 & $" \prime$ & 0.8 & 100 & 14 & 6,15 \\
\hline "l & $\|$ & $" \prime$ & $" 1$ & "l & 2.4 & 300 & 12 & 6.10 \\
\hline 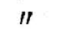 & "I & 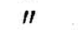 & $" \prime$ & " & 4 & 500 & 11 & 6.05 \\
\hline$" \prime$ & $" 1$ & $" \prime$ & $" \prime$ & $" \prime$ & 8 & 1000 & 7 & 6.13 \\
\hline$\prime \prime$ & $" 1$ & $" 1$ & $" \prime$ & $" 1$ & 12 & 1500 & 3 & 6.10 \\
\hline$" 1$ & " & 13.2 & 800 & "r & 0.8 & 100 & 11 & 6.10 \\
\hline$" \prime$ & "1 & "I & $" 1$ & $" t$ & 2.4 & 300 & 9 & 6.05 \\
\hline$" 1$ & $" 1$ & " & $" \prime$ & $"$ & 4 & 500 & 8 & 6.05 \\
\hline$"$ & "I & $" 1$ & $" 1$ & " & 8 & 1000 & 4 & 6.01 \\
\hline$" 1$ & $" 1$ & $" 1$ & "I & $" 1$ & 12 & 1500 & 0 & 6.00 \\
\hline
\end{tabular}


The data which the authors present should stimulate further work, which may lead eventually to a greater understanding of the biological system.

\section{Acknowledgements}

Dr. Genzo Hashizume (Research Institute of Industry, Hyogo Pref.) made available the $\mathrm{Ca}\left(\mathrm{HCO}_{3}\right)_{2} \cdot \mathrm{MgCl}_{2}$-organic material system at $20 \pm 1{ }^{\circ} \mathrm{C}$

\begin{tabular}{|c|c|c|c|c|c|c|c|}
\hline \multicolumn{8}{|c|}{ Carbonate formed during a 52 -day period } \\
\hline \multicolumn{2}{|c|}{$\begin{array}{c}\text { at the end } \\
\text { (on the } 52 \text { th day) }\end{array}$} & \multicolumn{2}{|c|}{ crystal form } & \multirow{2}{*}{$\begin{array}{c}\mathrm{MgCO}_{3} \text { content } \\
\text { determined } \\
\text { chemically } \\
\left(\frac{\mathrm{MgCO}_{3} \times 100}{\mathrm{CaCO}_{3}+\mathrm{MgCO}_{3}}\right) \\
\% \text { by weight }\end{array}$} & \multirow{2}{*}{$\begin{array}{c}\text { angle of } \\
\text { diffraction } \\
{ }^{\circ} \theta\end{array}$} & \multirow{2}{*}{$\begin{array}{c}\text { lattice } \\
\text { distance } \\
d(\AA)\end{array}$} & \multirow{2}{*}{$\begin{array}{c}\Delta d \\
d(\text { calcite }) \\
(3.037) \\
-d(\text { sample }) \\
\AA \\
\end{array}$} \\
\hline pH & $\begin{array}{c}\mathrm{Ca}^{2+} \\
\mathrm{mg}\end{array}$ & $\begin{array}{c}\text { calcite } \\
\%\end{array}$ & $\underset{\%}{\operatorname{aragonite}}$ & & & & \\
\hline $\begin{array}{l}8.65 \\
8.61 \\
8.64 \\
8.69 \\
8.70 \\
8.75 \\
8.88\end{array}$ & $\begin{array}{r}61 \\
72 \\
79 \\
79 \\
83 \\
97 \\
113\end{array}$ & $\begin{array}{c}100 \\
\prime \prime \\
\prime \prime \\
\prime \prime \\
\prime \prime \\
\prime \prime\end{array}$ & $\begin{array}{l}0 \\
\prime \prime \\
\prime \prime \\
\prime \prime \\
\prime \prime \\
\prime \prime \\
\prime \prime\end{array}$ & $\begin{array}{l}3.8 \\
3.8 \\
4.7 \\
4.8 \\
4.8 \\
4.8 \\
5.3\end{array}$ & $\begin{array}{l}14.779 \\
14.776 \\
14.786 \\
14.790 \\
14.805 \\
14.812 \\
14.812\end{array}$ & $\begin{array}{l}3.022 \\
3.023 \\
3.021 \\
3.020 \\
3.017 \\
3.016 \\
3.016\end{array}$ & $\begin{array}{l}0.015 \\
0.014 \\
0.016 \\
0.017 \\
0.020 \\
0.021 \\
0.021\end{array}$ \\
\hline $\begin{array}{l}8.65 \\
8.68 \\
8.72 \\
8.80\end{array}$ & $\begin{array}{r}82 \\
92 \\
100 \\
115\end{array}$ & $\begin{array}{l}\prime \prime \\
" 1 \\
" \prime\end{array}$ & $\begin{array}{l}\prime \prime \\
" \prime \\
\prime \prime\end{array}$ & $\begin{array}{l}6.7 \\
7.3 \\
8.2 \\
9.2\end{array}$ & $\begin{array}{l}14.819 \\
14.841 \\
14.879 \\
14.890\end{array}$ & $\begin{array}{l}3.014 \\
3.010 \\
3.002 \\
3.000\end{array}$ & $\begin{array}{l}0.023 \\
0.027 \\
0035 \\
0.037\end{array}$ \\
\hline $\begin{array}{l}8.62 \\
8.62 \\
8.60 \\
8.62 \\
8.66 \\
8.70 \\
8.84\end{array}$ & $\begin{array}{r}76 \\
81 \\
86 \\
94 \\
101 \\
117 \\
135\end{array}$ & $\begin{array}{l}\prime \prime \\
\prime \prime \\
\prime \prime \\
\prime \prime \\
\prime \prime \\
\prime \prime\end{array}$ & $\begin{array}{l}\prime \prime \\
\prime \prime \\
\prime \prime \\
\prime \prime \\
\prime \prime \\
\prime \prime\end{array}$ & $\begin{array}{r}8.4 \\
8.2 \\
90 \\
9.2 \\
9.0 \\
10.8 \\
11.5\end{array}$ & $\begin{array}{l}14.862 \\
14.867 \\
14880 \\
14.884 \\
14.889 \\
14.937 \\
14.950\end{array}$ & $\begin{array}{l}3.005 \\
3.044 \\
3.002 \\
3.001 \\
3.001 \\
2.990 \\
2.988\end{array}$ & $\begin{array}{l}0.032 \\
0.033 \\
0.035 \\
0.036 \\
0.036 \\
0.047 \\
0.049\end{array}$ \\
\hline $\begin{array}{l}8.58 \\
8.56 \\
8.62 \\
8.68 \\
8.75\end{array}$ & $\begin{array}{r}80 \\
93 \\
108 \\
131 \\
149\end{array}$ & $\begin{array}{l}\prime \prime \\
\prime \prime \\
\prime \prime \\
\prime \prime\end{array}$ & $\begin{array}{l}\prime \prime \\
\prime \prime \\
\prime \prime \\
\prime \prime\end{array}$ & $\begin{array}{r}9.3 \\
10.5 \\
10.3 \\
12.5 \\
12.0\end{array}$ & $\begin{array}{l}14.891 \\
14.915 \\
14.937 \\
14.977 \\
14.959\end{array}$ & $\begin{array}{l}3.000 \\
2.995 \\
2.990 \\
2.983 \\
2.987\end{array}$ & $\begin{array}{l}0.037 \\
0.042 \\
0.047 \\
0.054 \\
0.050\end{array}$ \\
\hline $\begin{array}{l}8.60 \\
8.65 \\
8.67 \\
8.61 \\
8.55\end{array}$ & $\begin{array}{l}48 \\
48 \\
52 \\
68 \\
89\end{array}$ & $\begin{array}{c}100 \\
\prime \prime \\
\prime \prime \\
\prime \prime\end{array}$ & $\begin{array}{l}0 \\
" \prime \\
\prime \prime \\
\prime \prime\end{array}$ & $\begin{array}{l}3.4 \\
4.4 \\
4.3 \\
4.8 \\
5.6\end{array}$ & $\begin{array}{l}14.802 \\
14.800 \\
14.791 \\
14.837 \\
14.821\end{array}$ & $\begin{array}{l}3.017 \\
3.018 \\
3.020 \\
3.010 \\
3.014\end{array}$ & $\begin{array}{l}0.020 \\
0.019 \\
0.017 \\
0.027 \\
0.023\end{array}$ \\
\hline $\begin{array}{l}8.58 \\
8.59 \\
8.50 \\
8.68 \\
8.70\end{array}$ & $\begin{array}{l}59 \\
64 \\
72 \\
78 \\
78\end{array}$ & $\begin{array}{l}\prime \prime \\
\prime \prime \\
\prime \prime \\
\prime \prime\end{array}$ & $\begin{array}{l}\prime \prime \\
" \prime \\
\prime \prime \\
" \prime\end{array}$ & $\begin{array}{l}5.0 \\
5.0 \\
6.6 \\
7.2 \\
8.1\end{array}$ & $\begin{array}{l}14.851 \\
14.850 \\
14.850 \\
14.864 \\
14.864\end{array}$ & $\begin{array}{l}3.008 \\
3.008 \\
3.008 \\
3.006 \\
3.00 j\end{array}$ & $\begin{array}{l}0.029 \\
0.029 \\
0.029 \\
0.031 \\
0.031\end{array}$ \\
\hline $\begin{array}{l}8.59 \\
8.50 \\
8.54 \\
8.70 \\
8.72\end{array}$ & $\begin{array}{r}65 \\
73 \\
75 \\
82 \\
100\end{array}$ & $\begin{array}{l}\prime \prime \\
" \prime \\
" \prime\end{array}$ & $\begin{array}{l}\prime \prime \\
" \prime \\
" \prime \\
\prime \prime\end{array}$ & $\begin{array}{l}7.2 \\
8.1 \\
8.7 \\
9.0 \\
9.7\end{array}$ & $\begin{array}{l}14.856 \\
14.867 \\
14.879 \\
14.912 \\
14.936\end{array}$ & $\begin{array}{l}3.008 \\
3.004 \\
3.002 \\
2.990 \\
2.990\end{array}$ & $\begin{array}{l}0.029 \\
0.030 \\
0.035 \\
0.041 \\
0.047\end{array}$ \\
\hline $\begin{array}{l}840 \\
8.50 \\
8.60 \\
8.68 \\
8.72\end{array}$ & $\begin{array}{l}42 \\
68 \\
69 \\
74 \\
70\end{array}$ & $\begin{array}{l}43 \\
88 \\
90 \\
89 \\
95\end{array}$ & $\begin{array}{r}57 \\
12 \\
10 \\
11 \\
5\end{array}$ & $\begin{array}{r}8.3 \text { (in calcite } \\
9.3 \text { (portion) } \\
9.5(1 ") \\
10.0\left({ }^{\prime}\right) \\
10.3(1 ")\end{array}$ & $\begin{array}{l}14.889 \\
14.894 \\
14.912 \\
14.939 \\
14.937\end{array}$ & $\begin{array}{l}3001 \\
3.000 \\
2.990 \\
2.990 \\
2.990\end{array}$ & $\begin{array}{l}0.036 \\
0.037 \\
0.041 \\
0.047 \\
0.047\end{array}$ \\
\hline
\end{tabular}


Table 2. Formation of magnesian calcite in $\mathrm{Ca}\left(\mathrm{HCO}_{3}\right)_{2}-\mathrm{MgCl}_{2}$-organic material system at various temperatures

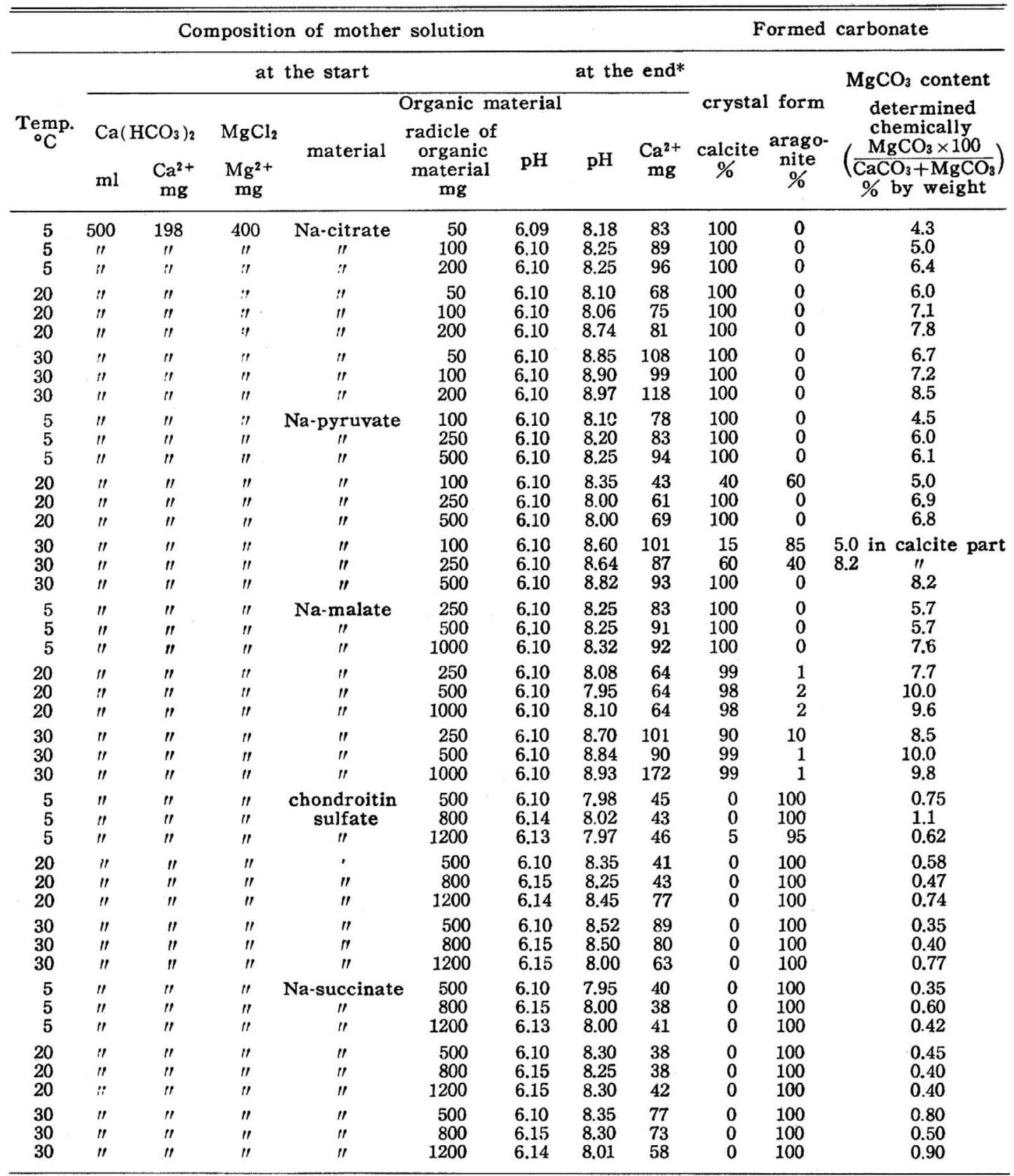

* Carbonate samples were precipitated at $5^{\circ} \mathrm{C}$ during a 71 -day period, at $20^{\circ} \mathrm{C}$ during a 44-day period, and at $30^{\circ} \mathrm{C}$ during a 16-day period. 
$\mathrm{X}$-ray spectrometer.

Professor KEITH E. CHAVE (Lehigh University, Bethlehem) and Dr. BRIAN W. LOGAN (University of Western Australia, Nedlands) discussed and helpfully criticized various stages of this work and preparation of this manuscript. They are gratefully acknowledged.

\section{References}

ChAve, K. E. (1952) A solid solution between calcite and dolomite. J. Geol. 60, 190-192.

CHAVE, K. E. (1954) Aspects of biogeochemistry of magnesium, 1. Calcareous marine organisms. ibid. 62, 266-283.

CHAVE, K. E. (1962) Factors influencing the mineralogy of carbonate sediments. Limnol. Oceanogr. 7, 218-223.

Chave, K. E., Deffeyes, K. S., Weyl, P. K., Garrels, R. M., and Thompson, M. E. (1962) Observations on the solubility of skeletal carbonates in aqueuus solutions. Science 137, No. 3523, 33-34.

GolDSMITH, J. R. (1959) Some aspects of the geochemistry of carbonates in Researches in Geochemistry (New York, John Wiley and Sons, Inc.) 336-385.

Goldsmith, J. R. and HEARD, H. C. (1961) Subsolidus phase relations in the system $\mathrm{CaCO}_{3}$ $\mathrm{MgCO}_{3}$, J. Geol. 69, 45-74.

GRAF, D. L. and GolDSMITH, J. R. (1955) Dolomite-magnesian calcite relations at elevated temperatures and $\mathrm{CO}_{2}$ pressures. Geochim. Cosmochim. Acta 7, 109-128.

HARKER, R. I, and TUtTle, O. F. (1955) Studies in the system CaO-MgO-CO , Part II. Limits of solid solution along the binary join, $\mathrm{CaCO}_{3}-\mathrm{MgCO}_{3}$. Am. J. Sci. 253, 274-282.

JANSEN, J. F. and KITANO, Y. (1963) The resistance of recent marine carbonate sediments to solution. J. Oceanogr. Soc. Japan 18, 42-53.

KANAMORI and KITANO (1966) Colorimetric determination of small amounts of magnesium in natural waters and carbonate sediments. J. Earth. Sci., Nagoya Univ. 14, (in press)

KITANO, Y. and FURUTSU, T. (1959) The state of a small amounts of magnesium contained in calcareous shells. Bull. Chem. Soc. Japan 33, 1-4.

KITANO, Y. (1962a) Behavior of various inorganic ions in the process of calcium carbonate separation from bicarbonate solution. ibid. 35, 1973-1980.

KITANO, Y. (1962 b) A study of polymorphic formation of calcium carbonate in thermal spring with emphasis on the temperature. ibid. 35, 1980-1985.

KITANO, Y. and HOOD, D. W. (1962) Calcium carbonate crystal forms formed from sea water by inorganic processes. J. Oceanogr. Soc. Japan 18, 35-39.

KITANO, Y., PARK, K., and HoOD, D. W. (1962) Pure aragonite synthesis. J. Geophy. Research 67, $4873-4874$.

KITANO, Y. (1964) On factors influencing the polymorphic crystallization of calcium carbonate found in marine biological systems in Recent researches in the fields of hydrosphere, atmosphere and nuclear geochemistry (Maruzen Co. Ltd., Tokyo, Japan) 305-319.

KITANO, Y. and HOOD, D. W. (1965) The influence of organic material on the polymorphic crystallization of calcium carbonate. Geochim. Cosmochim. Acta 29, 29-41.

LIPPMANN, F. (1960) Versuche zur Aufklärung der Bildungsbedingungen von Calcit und Aragonit, Fortschr. Miner. 38, 156-161.

LoWENSTAM, H. A. (1954) Factors affecting the aragonite: calcite ratios in carbonate secreting marine organisms. J. Geol. 62, 284-322.

LowENSTAM, H. A. (1961) Mineralogy, $\mathrm{O}^{18} / \mathrm{O}^{16}$ ratios, and strontium and magnesium contents of recent and fossil brachiopods and their bearing on history of the oceans. ibid. 69, 241260.

LOWENSTAM, H. A. (1963) Biologic problems relating to the composition and diagenesis of sediments in The earth sciences. (The Univ. Chicago Press.) 137-195. 
PILKEY, O. H. and Hower, J. (1960) The effect of environment on the concentration of skeletal magnesium and strontium in Dendraster. J. Gecl. 68, 203-214.

Pilkey, O. H. and Goodell, H. G. (1963) Trace elements in recent mollusk shells, Limnol. Oceanogr. 8, 137-148.

SIMKISS, K. (1964) Variations in the crystalline form of calcium carbonate precipitated from artificial sea water. Nature 201, No. 4918, 492-493.

WATABE, N. and WILBUR, K. M. (1960) Influence of the organic matrix on crystal type in molluscs. ibid. 188, 334 .

WILBUR, K. M. (1960) Shell structure and mineralization in molluscs in Calcification in biological system. Amer. Ass. Advanc. Sci. (Washington D. C.) 15-40.

WILBUR, K. M. and WATABE, N. (1963) Experimental studies on calcification in molluscs and the Alga coccolithus huxleyi in Comparative biology of calcified tissue (Annal. New York Aca. Sciences) 82-112. 